\title{
Remediation of $\operatorname{Cr}(\mathrm{VI})$ using $\mathrm{C}_{3} \mathrm{~N}_{4} / \mathrm{DEU}-\mathbf{5 1}(\mathrm{Fe})$ under sun light irradiation Güneș ışığı altında $C_{3} \mathrm{~N}_{4} / \mathrm{DEU}-51(\mathrm{Fe})$ kullanılarak $\mathrm{Cr}(\mathrm{VI})$ 'nın giderimi
}

\author{
Sevil AKÇAĞLAR ${ }^{1 *}$ iD
}

${ }^{1}$ Mechanical Engineering, Engineering Faculty, Dokuz Eylül University, Izmir, Turkey. sevil.akcaglar@deu.edu.tr

\begin{abstract}
$\overline{\text { A hybrid nanocomposite namely } C_{3} N_{4} / D E U-51(\mathrm{Fe}) \text { was developed to }}$ reduce the $\operatorname{Cr}(V I)$ from a textile industry wastewater. $C_{3} N_{4} / D E U-51(F e)$ exhibited a good cristalinity. The photocatalytic reaction of the carboxyl groups of the composite is in center and it is associated with the $\mathrm{C}$-H-vibration. The optimal doping content of $C_{3} N_{4} / D E U-51(\mathrm{Fe})$ was determined to be $1.2 \mathrm{mg} / \mathrm{L}$ to treat $1.6 \mathrm{mg} / \mathrm{L}$ $\mathrm{Cr}(\mathrm{VI})$ with a maximum yield of $98 \%$ at a sun light power of $80 \mathrm{~mW} / \mathrm{m}^{2}$ after 15 min at $42^{\circ} \mathrm{C}$ in summer. After $5^{\text {th }}$ times sun light experiments, the $C_{3} N_{4} / D E U-51(\mathrm{Fe})$ was reused with a yield of $97 \%$. The $\mathrm{Cr}(\mathrm{VI})$ reduction was explained with the Langmuir-Hinshelwood $(\mathrm{L}-\mathrm{H})$ kinetic model.
\end{abstract}

Keywords: $\quad \mathrm{Cr}(\mathrm{VI}), \quad \mathrm{C}_{3} \mathrm{~N}_{4} / \mathrm{DEU}-51(\mathrm{Fe}), \quad$ Langmuir-Hinshelwood photo-degradation kinetic, Reuse, Sun light.

\section{Introduction}

Heavy metal pollution is increasing significantly since the disposal of wastewater is an important environmental problem. Wastewaters from chemical, textile, glass and metal industries includes toxic heavy metals at high concentrations [1]-[3]. The environmental pollution caused by organic and inorganic pollutants increase the pollution problem because of rapid industrialization. Metals released to aquatic ecosystems as a result human activities, from soils and rocks concerning the discharge of metals from metal, chemical, petrochemical and metallurgical industries [4]. The big part of heavy metal pollutants are zinc, chromium, nickel and lead [5]. $(\mathrm{Cr}(\mathrm{VI}))$ is a metal present in the receiving aquatic ecocystems released wastewaters like metal, petrochemical, textile, leather and metal finishing [6]-[9].

The utilization of photo catalysts under sunlights increase the photodegradation mechanism by elevating the removal of resistant compounds. With good absorption under crosssection areas under solar spectrum, increase the conversion efficiency of pollutant in different environments with low cost [7],[10]. Cost is very significant in the comparison of the efficiency of the nano-adsorbents. A nono adsorbent should be cost effective. Improved adsorption capacities should be attributed to the low cost of adsorbents [11],[12]. With photocatalytic applications metals oxides can be converted to the other metals under UV light. The adsorbents it is used successfully in the removals of expensive by the industries and cause to environmental pollution [13]. Therefore, it is important to generate some cheap new metal-free catalysts activated under sun light and exhibiting good photocatalytic
Öz

$\mathrm{C}_{3} \mathrm{~N}_{4} / \mathrm{DEU}-51(\mathrm{Fe})$ hibrit nanokompoziti bir tekstil endüstrisi atık suyundaki $C r(V I)$ 'yı azaltmak için geliștirilmiștir. $C_{3} N_{4} / D E U-51(\mathrm{Fe})$ kristal özellikli olup bu kompozitin merkezindeki karboksil gruplarının fotoparçalanma reaksiyonu $\mathrm{C}-\mathrm{H}$ bağlanmasıly ilgilidir. $1.6 \mathrm{mg} / \mathrm{L}$ $\operatorname{Cr}(V I)$ 'yl yaz ayında \%98'lik maksimum verimle gidermek için optimum koșullar; $1.2 \mathrm{mg} / \mathrm{L} C_{3} N_{4} / D E U-51(\mathrm{Fe}), 15 \mathrm{dk}$. temas süresi, $80 \mathrm{~mW} / \mathrm{m}^{2}$ güneș ışığı șiddeti ve $42{ }^{\circ} \mathrm{C}$ sıcaklıktır. $C_{3} N_{4} / D E U-$ 51(Fe)nanopartikülü $5 \mathrm{kez}$ kullanıldıktan sonra \%97 verimle geri kullanılmıștır. Cr(VI) giderimi Langmuir-Hinshelwood (L-H) kinetik modelle açıklanmıştır. Cr(VI) giderimi Langmuir-Hinshelwood (L-H) kinetik modelle açıklanmıștır.

Anahtar kelimeler: $\quad \mathrm{Cr}(\mathrm{VI}), \mathrm{C}_{3} \mathrm{~N}_{4} / \mathrm{DEU}-51(\mathrm{Fe}), \quad$ LangmuirHinshelwood foto parçalanma kinetiği, Geri kullanım, Güneș Ișığı.

performance and they are friendly in environmental ecosystems [14]. For this reason, degradation of $\mathrm{Cr}(\mathrm{VI})$ to $\mathrm{Cr}$ (III) can be usefull for the environment and ecosystem.

In this study, Fe-based carbon nitride $\mathrm{C}_{3} \mathrm{H}_{4}$ nanocomposite was developed under laboratory conditions and it was used to reduce $\mathrm{Cr}(\mathrm{VI})$. The different concentrations of $\mathrm{C}_{3} \mathrm{~N}_{4}(0.05 \mathrm{mg} / \mathrm{L}$, $0.1,0.3,0.7,1.0,1.5,2.3$ and $5 \mathrm{mg} / \mathrm{L}$ ) in $\mathrm{C}_{3} \mathrm{~N}_{4} / \mathrm{DEU}-51(\mathrm{Fe})$, the effects of increasing photooxidation times ( $5 \mathrm{~min}, 15 \mathrm{~min}, 35$ $\mathrm{min}, 60 \mathrm{~min}$ and $90 \mathrm{~min}$ ), the effects of increasing sun light powers $\left(25 \mathrm{~mW} / \mathrm{m}^{2}\right.$ at $12: 00$ in winter, $80 \mathrm{~mW} / \mathrm{m}^{2}$ at $12: 00$ in summer, $55 \mathrm{~mW} / \mathrm{m}^{2}$ at $12: 00$ in spring and $35 \mathrm{~mW} / \mathrm{m}^{2}$ at $12: 00$ in autumn), effect of temperature $\left(10^{\circ} \mathrm{C}\right.$ in winter at $12: 00$; $23{ }^{\circ} \mathrm{C}$ in spring, at $12: 00 ; 42{ }^{\circ} \mathrm{C}$ in summer at $12: 00$ and $26^{\circ} \mathrm{C}$ in autumn at 12:00), effect of $\mathrm{pH}(2,7$ and 10) on the removals of $\mathrm{Cr}$ (VI) were researched. The reusability performance of $\mathrm{C}_{3} \mathrm{~N}_{4} / \mathrm{DEU}-51(\mathrm{Fe})$ and the $\mathrm{Cr}(\mathrm{VI})$ reduction by LangmuirHinshelwood kinetic model was researched.

\section{Materials and methods}

\subsection{Production of DEU-51(Fe) under laboratory conditions}

1,4-benzenedicarboxylate (1.4-BDC) (1.69 g) and $\mathrm{FeCl}_{3} 6 \mathrm{H}_{2} \mathrm{O}$ $(2.12 \mathrm{~g})$ were added into $50 \mathrm{~mL} \mathrm{~N}, \mathrm{~N}$-dimethylformamide (DMF) and was mixed in a magnetic stirrer homogeneously. Then they were transferred into a $100 \mathrm{~mL}$ Teflon cap and it was incubated at $150{ }^{\circ} \mathrm{C}$ for $24 \mathrm{~h}$. It was cooled in room temperature. The product was centrifugated, then it was rinsed with DMF and ethanol, respectively. The obtained sample dehydreted in an incubator at $150{ }^{\circ} \mathrm{C}$ for $24 \mathrm{~h} \mathrm{[15].}$ 


\subsection{Production of $\mathrm{C}_{3} \mathrm{~N}_{4}$ under laboratory conditions}

The $\mathrm{C}_{3} \mathrm{~N}_{4}$ was produced with calcination of melamine [16]. $1.3 \mathrm{~g}$ melamine was added into a ceramic cup containing a cover, and then the produced matter was boiled at $560{ }^{\circ} \mathrm{C}$ in an incubator for $6 \mathrm{~h}$. The product was utilized to produce the composite [15].

\subsection{Production of $\mathrm{C}_{3} \mathrm{~N}_{4} / \mathrm{DEU}-\mathbf{5 1}(\mathrm{Fe})$ under laboratory conditions}

$3 \mathrm{~g} \mathrm{C}_{3} \mathrm{~N}_{4}$ was put into10 mL DMF. This mixture ultrasonicated for $35 \mathrm{~min}$. $1.76 \mathrm{~g}$ of $1.4-\mathrm{BDC}$ and $4.89 \mathrm{~g} \mathrm{FeCl}{ }_{3} 6 \mathrm{H}_{2} \mathrm{O}$ were transferred to $56 \mathrm{~mL}$ DMF. They stirred until became homogenous. $\mathrm{C}_{3} \mathrm{~N}_{4} / \mathrm{DMF}$ was successively settled in the mixture. It heated at an furnace of $150^{\circ} \mathrm{C}$ for 1 day. The products were $\mathrm{CMFe}-3$ and $\mathrm{CMFe}-5$. They identified based on $\mathrm{C}$ and $\mathrm{N}$ (3 \% and $5 \%$ ) percentages [15].

\subsection{Photocatalytic removal of $\mathrm{Cr}$ (VI)}

The photodegradation yield was measured by removing of $\mathrm{Cr}(\mathrm{VI})$ to $\mathrm{Cr}(\mathrm{III})$. Using different $\mathrm{C}_{3} \mathrm{~N}_{4} / \mathrm{DEU}-51(\mathrm{Fe})(0.1$ $\mathrm{mg} / \mathrm{L}, 0.3,0.8,1,1.2,1.6,1.8,2.5$ and $4 \mathrm{mg} / \mathrm{L}$ ) concentrations the reducing of $6 \mathrm{mg} / \mathrm{L}$ initial $\mathrm{Cr}(\mathrm{VI})$ solution were investigated.

\subsection{Solar reactor}

The solar reactor was made from a resistant quartz material

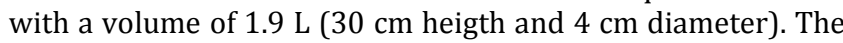
UV studies were performed under constant sun ligths at powers varying between $70.00-80.00 \mathrm{~mW} / \mathrm{m}^{2}$ at hours between 11:00 am and 16:00 pm when the sunligth powers were at maximum levels.

\subsection{Power of sunlight}

The intensities of sunlight photoreactor were $25 \mathrm{~mW} / \mathrm{m}^{2}$ at 12:00 in winter, $80 \mathrm{~mW} / \mathrm{m}^{2}$ at $12: 00$ in summer, $55 \mathrm{~mW} / \mathrm{m}^{2}$ at 12:00 in spring and $35 \mathrm{~mW} / \mathrm{m}^{2}$ at 12:00 in autumn. Sunlight powers were measured with a Philips light meter Model DL-2001 during months and days.

\subsection{Measurements of $\operatorname{Cr}$ (VI) and $\operatorname{Cr}$ (III) concentrations}

$\mathrm{Cr}(\mathrm{VI})$ was detected in an chromatographic device containing a visible wavelength detector. The IC/PCR distinguish the $\mathrm{Cr}^{+6}$ as $\mathrm{CrO}^{4}=$ from other diphenyl reactions with carbazide. Reduction $\mathrm{Cr}(\mathrm{III})$ to $\mathrm{Cr}(\mathrm{VI})$ was performed according to the literature given by Gürkan et al. [17]. The $\mathrm{pH}$ was regulated to $\mathrm{pH} 10$ by adding $15 \mathrm{~mL} 4 \%(\mathrm{w} / \mathrm{w}) \mathrm{H}_{2} \mathrm{O}_{2}$. This sol was heated in an incubator at $80^{\circ} \mathrm{C}$ during $50 \mathrm{~min}$. Then it was boiled in a heater for 15 min to treat the $\mathrm{H}_{2} \mathrm{O}_{2}$. $\mathrm{Cr}(\mathrm{VI})$ was calculated in a spectrophotometer at a wave length of $651 \mathrm{~nm} . \operatorname{Cr}(\mathrm{III})$ was measured by discarding $\mathrm{Cr}(\mathrm{VI})$ level from the total $\mathrm{Cr}$.

\subsection{Characterization of $\mathrm{C}_{3} \mathrm{~N}_{4}$, DEU-51(Fe) and $\mathrm{C}_{3} \mathrm{~N}_{4} / \mathrm{DEU}-\mathbf{5 1}(\mathrm{Fe})$}

X-Ray Diffractometer (XRD) running at $40 \mathrm{~mA}$ and $40 \mathrm{kV}$ $(\mathrm{Cu}-\mathrm{K})$ was used while a Fourier Transform Infrared (FTIR) spectroscopy on $\mathrm{KBr}$ was utilized in a Transmission FTIR Spectrometric Analyzer. Transmission Electron Microscope (TEM) and Scanning Electron Microscope (SEM) data were collected by using TEM JEM-200 CX with an electrical voltage of $100 \mathrm{kV}$. Brunauer, Emmet and Teller (BET) analysis were performed to determine the surrounding area, the pore volume and the pore size distribution of the adsorbent using nitrogen adsorption method.

\section{Results and discussion}

\subsection{XRD patterns of $\mathrm{C}_{3} \mathrm{~N}_{4}$, DEU-51(Fe) and $\mathrm{C}_{3} \mathrm{~N}_{4} / \mathrm{DEU}-\mathbf{5 1}(\mathrm{Fe})$ for $0.5 \mathrm{mg}, 1.0$ and $2.0 \mathrm{mg}$}

The crystal composition of DEU-51(Fe) was researched using XRD. The XRD pathways of DEU-51(Fe) exhibiting similar data with the study's results by Akple et al. and Wen et al. $\mathrm{C}_{3} \mathrm{~N}_{4} / \mathrm{DEU}-51(\mathrm{Fe}), \quad \mathrm{C}_{3} \mathrm{~N}_{4}$ and DEU-51(Fe) [18],[19] (Figure 1a). The strong diffraction hills of DEU-51(Fe) showing the crystalloid structure of this adsorbent. The raised peaks in XRD pathways exhibited similarities with the studies performed recently [20]. The small hills results from the breathing of some small molecular organics in the solvents used in the production of DEU-51(Fe) (Figure 1a). Some solvents, like DMF and BDC leads to production of important changes of the lattice in the hill peaks. The distinctions peaks of $\mathrm{C}_{3} \mathrm{~N}_{4}$ exhibited similar data with the results of Lewellyn et al. and $\mathrm{Hu}$ et al. (Figure 1b) [21],[22]. The interlayer-stacking hill (0019) at $29.8^{\circ} \mathrm{C}$ attributed to the interlayer distance of $\sim 0.38 \mathrm{~nm}$ in the structure of $\mathrm{C}_{3} \mathrm{~N}_{4}$. The XRD patterns of $\mathrm{C}_{3} \mathrm{~N}_{4} / \mathrm{DEU}-51(\mathrm{Fe})$ showed a crystal constitution of the DEU-51(Fe). It was not varied after the supplementation of $\mathrm{C}_{3} \mathrm{~N}_{4}$ as reported by Wang et al. and Hong et al. [23],[24]. Figure 1c, indicates the XRDpatterns of $0.5 \mathrm{mg}, 1.0$ and $2.0 \mathrm{mg} \mathrm{C}_{3} \mathrm{~N}_{4} / \mathrm{DEU}-51(\mathrm{Fe})$. It was shown that the XRD pathways of the this composite exhibited similarities with the XRD patterns of DEU-51(Fe) and $\mathrm{C}_{3} \mathrm{~N}_{4}$. This showed that the crystal constitution of the DEU$51(\mathrm{Fe})$ is not varied after the supplementation of $\mathrm{C}_{3} \mathrm{~N}_{4}$. This result agree with the previous recent investigations [24],[25].

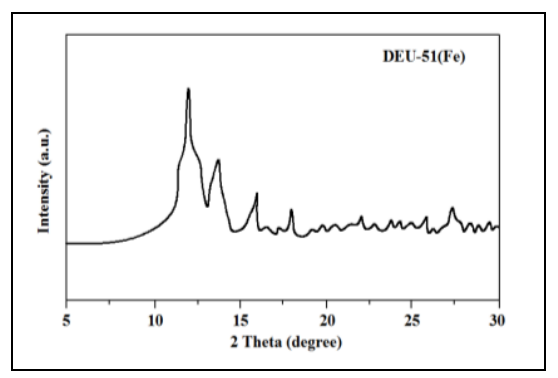

Figure 1a. XRD patterns of DEU-51(Fe).

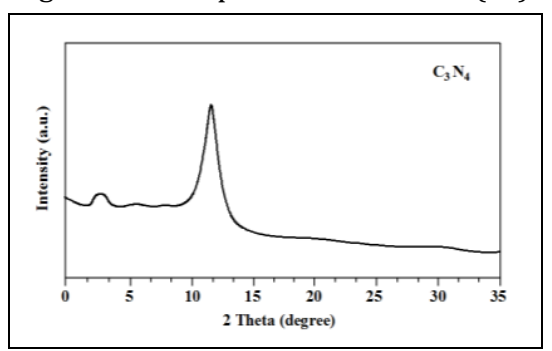

Figure 1b. XRD patterns of $\mathrm{C}_{3} \mathrm{~N}_{4}$.

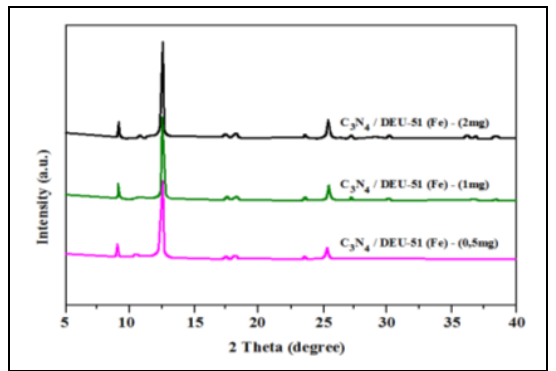

Figure 1c. XRD patterns of $\mathrm{C}_{3} \mathrm{~N}_{4} / \mathrm{DEU}-51(\mathrm{Fe})$. 


\subsection{FTIR spectra of $\mathrm{C}_{3} \mathrm{~N}_{4}$, DEU-51 (Fe) and $\mathrm{C}_{3} \mathrm{~N}_{4} / \mathrm{DEU}-\mathbf{5 1}(\mathrm{Fe})$}

The spectra of $\mathrm{C}_{3} \mathrm{~N}_{4}$ and the other constituents of nanocomposites are illustrated in Figure 2. This spectrum involved broad exceed bands at $3271 \mathrm{~cm}^{-1}, 3164 \mathrm{~cm}^{-1}$, and 3072 $\mathrm{cm}^{-1}$. These bands are related with the stretching pulses of $\mathrm{N}-\mathrm{H}$ bonds. More specific bands were detected at $1636 \mathrm{~cm}^{-1}, 1569$ $\mathrm{cm}^{-1}, 1410 \mathrm{~cm}^{-1}, 1326 \mathrm{~cm}^{-1}, 1242 \mathrm{~cm}^{-1}$ and $806 \mathrm{~cm}^{-1}$ indicating the characteristic of $\mathrm{C}_{3} \mathrm{~N}_{4}$ [21],[22],[24]. Powerful bands around $1636 \mathrm{~cm}^{-1}$ and $1242 \mathrm{~cm}^{-1}$ such as $\mathrm{C}=\mathrm{N}$ and $\mathrm{C}-\mathrm{N}$ illustrated different cyclic rings. The FTIR spectra of DEU-51(Fe) showed in Figure 2. This graph showed similar data based on vibration their structure. This contains trivalent metal cores and - $\mathrm{COOH}$ ligands. The absorption apicals of the DEU-51(Fe) were detected at around $1685 \mathrm{~cm}^{-1}, 1595,1396$, 1020 , and $750 \mathrm{~cm}^{-1}$. These hills were originated from the oscillation in the $\mathrm{COOH}$ groups compared to the recent literatures [26],[27]. The high intensity of (C-0) at around 1685 $\mathrm{cm}^{-1}$ indicates the availability of some free carboxylic groups [28]. The two strong peaks at around 1595 and $1396 \mathrm{~cm}^{-1}$ ( $(\mathrm{C}-\mathrm{O})$ and $(\mathrm{C}-\mathrm{O})$ ) exhibited the derivatives of carboxyl groups. This indicates the availability of Fe containing nanocomposites for effective adsorption. The FTIR spectrum of $\mathrm{C}_{3} \mathrm{~N}_{4} / \mathrm{DEU}-51(\mathrm{Fe})-(0,5 \mathrm{mg} ; 1$ and $2 \mathrm{mg})$ exhibits two bands at $1564 \mathrm{~cm}^{-1}$ and $1383 \mathrm{~cm}^{-1}$ (Figure 2). This is related with the absorption of the carboxyl groups on the center of $\mathrm{C}_{3} \mathrm{~N}_{4}$ /DEU - 51(Fe) composite. The strong band at $747 \mathrm{~cm}^{-1}$ is relevant to $\mathrm{C}$-H-puls. Both samples showed the same frequency dependence in the construction of nanocomposite. This showed that the structure of $\mathrm{C}_{3} \mathrm{~N}_{4} / \mathrm{DEU}-51(\mathrm{Fe})$ composite was not changed effectively.

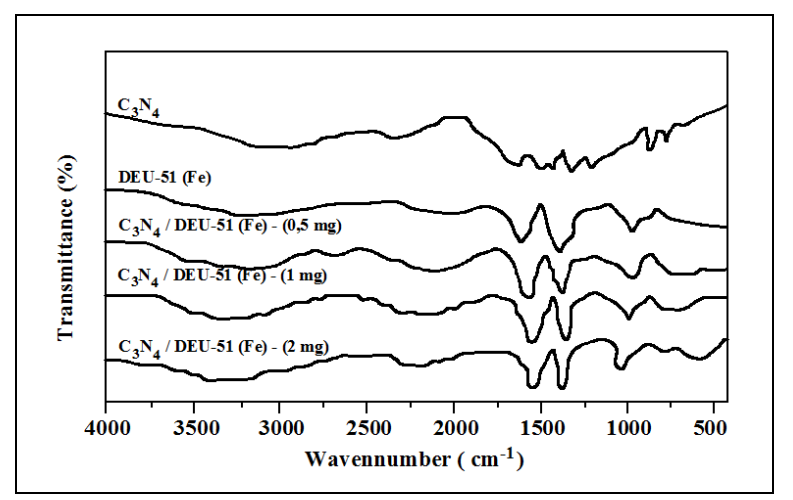

Figure 2. FTIR spectra of $\mathrm{C}_{3} \mathrm{~N}_{4}, \mathrm{DEU}-51(\mathrm{Fe})$ and $\mathrm{C}_{3} \mathrm{~N}_{4} / \mathrm{DEU}-51(\mathrm{Fe})$.

3.3 SEM images of DEU-51(Fe), $\mathrm{C}_{3} \mathrm{~N}_{4} / \mathrm{DEU}-\mathbf{5 1}(\mathrm{Fe})$; and TEM micrographs of $\mathrm{C}_{3} \mathrm{~N}_{4}, \mathrm{DEU}-51(\mathrm{Fe})$

As shown in Figure 3a, SEM images of DEU-51(Fe) exhibited a multiple hedron structure. The SEM picture of $\mathrm{C}_{3} \mathrm{~N}_{4} / \mathrm{DEU}-51(\mathrm{Fe})$ composite reveals $\mathrm{C}_{3} \mathrm{~N}_{4}$ coated on the DEU-51(Fe) showed similarities with the surface of composite (Figure $3 \mathrm{~b}$ ). Figure 3c exhibited the TEM micrographs of $\mathrm{C}_{3} \mathrm{~N}_{4}$ and DEU-51(Fe). This showed that the $\mathrm{C}_{3} \mathrm{~N}_{4}$ was greatly localized to the superficies of the $\mathrm{C}_{3} \mathrm{~N}_{4} / \mathrm{DEU}-51(\mathrm{Fe})$ composite.

\subsection{EDS measurement of $\mathrm{C}_{3} \mathrm{~N}_{4} / \mathrm{DEU}-51(\mathrm{Fe})$}

EDS analysis results showed that there are iron, carbon, oxygen and nitrogen elements in the structure of $\mathrm{C}_{3} \mathrm{~N}_{4} / \mathrm{DEU}-51(\mathrm{Fe})$ composite (Figure 4). The elements were distributed throughout $\mathrm{C}_{3} \mathrm{~N}_{4} / \mathrm{DEU}-51(\mathrm{Fe})$ composite.

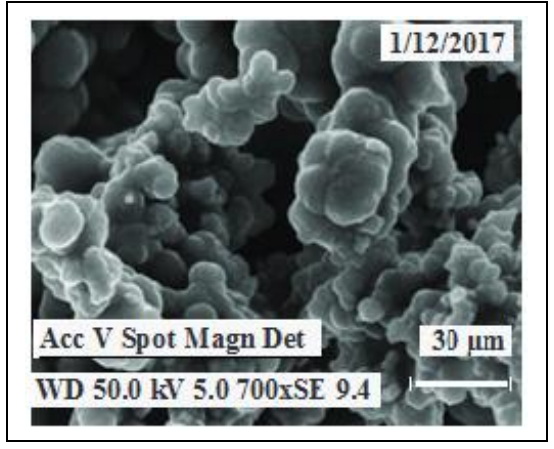

Figure 3(a). DEU-51(Fe).

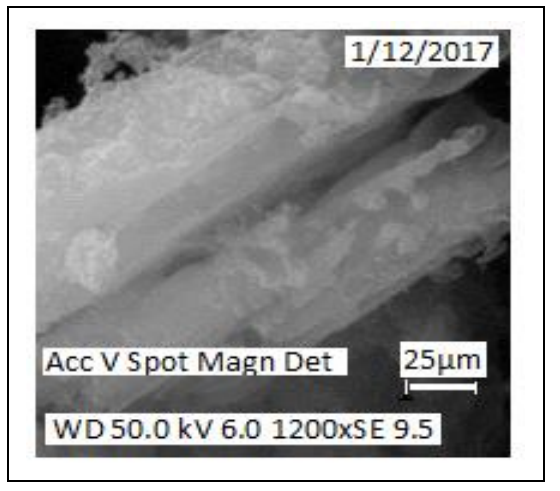

Figure 3(b). $\mathrm{C}_{3} \mathrm{~N}_{4} / \mathrm{DEU}-51(\mathrm{Fe})$.

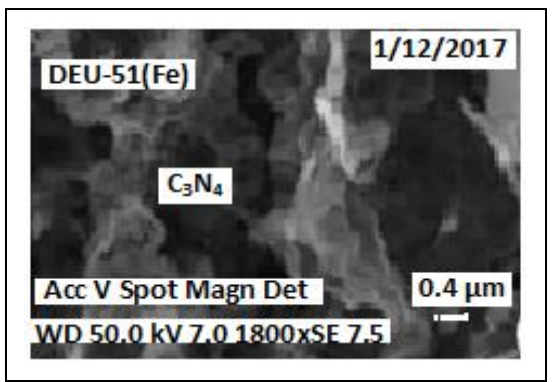

Figure 3(c). $\mathrm{C}_{3} \mathrm{~N}_{4}$ and DEU-51(Fe).

Figure 3. SEM images of DEU-51(Fe) (a) and $\mathrm{C}_{3} \mathrm{~N}_{4} / \mathrm{DEU}-$ 51(Fe)(b); TEM images of $\mathrm{C}_{3} \mathrm{~N}_{4}$ and DEU-51(Fe)(c).

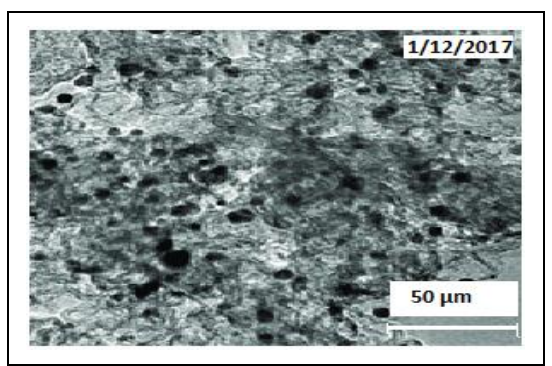

Figure 4. EDS measurement composite.

3.5 BET, pore volume and pore diameter analysis of $\mathrm{C}_{3} \mathrm{~N}_{4}$, DEU-51(Fe) and $\mathrm{C}_{3} \mathrm{~N}_{4} / \mathrm{DEU}-\mathbf{5 1}(\mathrm{Fe})$

The BET surface area of $\mathrm{C}_{3} \mathrm{~N}_{4} / \mathrm{DEU}-51(\mathrm{Fe})$ complete composite is $22.04 \mathrm{~m}^{2} \mathrm{~g}^{-1}$. It is over than pristine $\mathrm{C}_{3} \mathrm{~N}_{4}(13.5$ $\left.\mathrm{m}^{2} \mathrm{~g}^{-1}\right)$ and DEU-51(Fe) (12.8 $\left.\mathrm{m}^{2} \mathrm{~g}^{-1}\right)$ (Table 1). The mean pore radius of $\mathrm{C}_{3} \mathrm{~N}_{4} / \mathrm{DEU}-51(\mathrm{Fe})$ composite containing $\mathrm{Cr}(\mathrm{VI})$ is also bigger than that of pristine $\mathrm{C}_{3} \mathrm{~N}_{4} / \mathrm{DEU}-51(\mathrm{Fe})$ composite before $\mathrm{Cr}(\mathrm{VI})$ treatment. This can be explained with the surface of composite which is not occupied by $\mathrm{C}_{3} \mathrm{~N}_{4}$. 
The introduction of the $\mathrm{C}_{3} \mathrm{~N}_{4}$ to the $\mathrm{C}_{3} \mathrm{~N}_{4} / \mathrm{DEU}-51(\mathrm{Fe})$ composite does not influence the generation of the pure composite crystals to a certain extend.

3.6 Effects of doping content of $C_{3} N_{4}$ in the $1.6 \mathrm{mg} / \mathrm{L}$ $\mathrm{C}_{3} \mathrm{~N}_{4} / \mathrm{DEU}-\mathbf{5 1}(\mathrm{Fe})$ on the treatment of initial 6 $\mathrm{mg} / \mathrm{L} \mathrm{Cr}(\mathrm{VI})$ at a sun light power of $65 \mathrm{~mW} / \mathrm{m}^{2}$ after 14 min photoxidation

The effect of $\mathrm{C}_{3} \mathrm{~N}_{4}$ dose on the photocatalytic treatment of $\mathrm{Cr}(\mathrm{VI})$ was investigated for limits varying between 0.05-5.0 mg/L. The efficiencies were compared with a sample without catalyst. This phenomenon was determined as photolysis. Furthermore, a control was utilized to research the adsorption and desorption of $\mathrm{Cr}(\mathrm{VI})$ on the $\mathrm{C}_{3} \mathrm{~N}_{4}$ surface under sun light. As the $\mathrm{C}_{3} \mathrm{~N}_{4}$ concentration was increased from $0.05 \mathrm{mg} / \mathrm{L}$ up to $0.7 \mathrm{mg} / \mathrm{L}$, the $\mathrm{Cr}(\mathrm{VI})$ concentrations reduced to $0.83 \mathrm{mg} / \mathrm{L}$ with a $\mathrm{Cr}(\mathrm{VI})$ yield of $93 \%$ (Table 2). Further increase of $\mathrm{C}_{3} \mathrm{~N}_{4}$ concentration up to 2.3 and $5.6 \mathrm{mg} / \mathrm{L}$ the $\mathrm{Cr}(\mathrm{VI})$ removals remained stable. The maximum $\mathrm{Cr}(\mathrm{VI})$ yields was obtained at $0.70 \mathrm{mg} / \mathrm{L} \mathrm{C}_{3} \mathrm{~N}_{4}$ concentration. About 0,8-1,2 \% removal in the level of $\mathrm{Cr}(\mathrm{VI})$ was detected after $20 \mathrm{~min}$ of adsorption under dark circumtances. The level of $\mathrm{Cr}$ (VI) did not modify during $60 \mathrm{~min}$ (data not shown). For this reason, the $\mathrm{Cr}$ (VI) mixed with the $\mathrm{C}_{3} \mathrm{~N}_{4}$ during $10 \mathrm{~min}$ in order to reach the steady-state conditions for adsorption and desorption processes under dark conditions. It was not found a big removal in the $\mathrm{Cr}$ (VI) concentrations during photolysis. However addition of $0,7 \mathrm{mg} / \mathrm{L}$ of $\mathrm{C}_{3} \mathrm{~N}_{4}$ catalyst increase the photodegradation of pollutant. At a lower $\mathrm{C}_{3} \mathrm{~N}_{4}$ concentrations ( 0.05 and $0.1 \mathrm{mg} / \mathrm{L})$ the $\mathrm{Cr}(\mathrm{VI})$ removal yield was $45-55 \%$ after 15 min photocatalysis. When the $\mathrm{C}_{3} \mathrm{~N}_{4}$ level increased $(0.30 \mathrm{mg} / \mathrm{L}$ and $0.7 \mathrm{mg} / \mathrm{L}) ; 65 \%$ and $93 \% \mathrm{Cr}(\mathrm{VI})$ treatment efficiencies was observed, respectively. The increasing of the $\mathrm{C}_{3} \mathrm{~N}_{4}$ catalyst $(1.00 \mathrm{mg} / \mathrm{L}, 1.50$ and $5 \mathrm{mg} / \mathrm{L}$ ) lowered the yield of $\mathrm{Cr}(\mathrm{VI})(92 \%)$. Therefore, $0.7 \mathrm{mg} / \mathrm{L} \mathrm{C}_{3} \mathrm{~N}_{4}$ was accepted as an optimum concentration for the studies performed during the experiments. At his $\mathrm{C}_{3} \mathrm{~N}_{4}$ levels the photocatalytic yield for $\mathrm{Cr}(\mathrm{VI})$ removal was detected via good electron transferring during effective sun light absorption. The optimum catalyst concentration was chosen when the reactive oxygen species are optimum to remove the $\mathrm{Cr}(\mathrm{VI})$. Optimum concentration can be defined as the equilibrium between free radicals and shifting due to the presence of excess $\mathrm{C}_{3} \mathrm{~N}_{4}$. Similarly, Huang at al. also detected an optimum $\mathrm{g}-\mathrm{C}_{3} \mathrm{~N}_{4}$ concentration in the $\mathrm{g}-\mathrm{C}_{3} \mathrm{~N}_{4}$, MIL-53(Fe) showed better $\mathrm{Cr}(\mathrm{VI})$ yield, compared to MIL$53(\mathrm{Fe})[15]$. It was declared that high electron migration yield exhibits an important way to rise the photocatalytic yield. This is very important since rich electron transfer can decrease the redox of electron-cavity pairs [15]. Wan et al. and Wang et al. investigated the impact of nanocomposite level on photodegradaion of $\mathrm{Cr}(\mathrm{VI})$ under visible light. They observed efficient $\mathrm{Cr}(\mathrm{VI})$ yield (85\%) under sunlight using $0.8 \mathrm{~g} / \mathrm{L}$ g- $\mathrm{C}_{3} \mathrm{~N}_{4}$ /graphene under optimum conditions [29],[30].

\subsection{Effects of $\mathrm{C}_{3} \mathrm{~N}_{4} / \mathrm{DEU}-\mathbf{5 1}(\mathrm{Fe})$ concentrations on the treatment of $\mathrm{Cr}(\mathrm{VI})$ at $0,7 \mathrm{mg} / \mathrm{L} \mathrm{C}_{3} \mathrm{~N}_{4}$ concentration at initial $6 \mathrm{mg} / \mathrm{L} \mathrm{Cr}(\mathrm{VI})$ at a sun light power of $65 \mathrm{~mW} / \mathrm{m}^{2}$ after $14 \mathrm{~min}$ photooxidation}

$\mathrm{C}_{3} \mathrm{~N}_{4} / \mathrm{DEU}-51(\mathrm{Fe})$ levels were raised from $0.1 \mathrm{mg} / \mathrm{L}$ up to $4 \mathrm{mg} / \mathrm{L}$. As the $\mathrm{C}_{3} \mathrm{~N}_{4} / \mathrm{DEU}-51(\mathrm{Fe})$ level was enhanced from $0.1 \mathrm{mg} / \mathrm{L}$ up to $1.2 \mathrm{mg} / \mathrm{L}$ the $\mathrm{Cr}(\mathrm{VI})$ yields increased from $34 \%$ up to $93 \%$ (Table 3). Further increase of this nanocomposite did not affect the $\mathrm{Cr}(\mathrm{VI})$ removals. The effective $\mathrm{Cr}(\mathrm{VI})$ photooxidation was obtained at $1.2 \mathrm{mg} / \mathrm{L} \mathrm{C}_{3} \mathrm{~N}_{4} / \mathrm{DEU}-51(\mathrm{Fe})$ levels. The lowest $\mathrm{Cr}(\mathrm{VI})$ photooxidation was obtained at $0.1 \mathrm{mg} / \mathrm{L} \mathrm{C}_{3} \mathrm{~N}_{4} / \mathrm{DEU}-51(\mathrm{Fe})$ levels as $34 \%$. An increase of $\mathrm{C}_{3} \mathrm{~N}_{4}$ /DEU - 51(Fe) loading advices to elevate the activated regions, however, can be decrease the reduction of $\mathrm{Cr}(\mathrm{IV})$ by blocking sun irradiation.

Nguyen and Juang reported that the increase of catalyst increased the reduction efficiency of pollutant because catalyst exhibits a high capacity for promoting the intreaction between oh radicals and pollutants [31]. In this study, $\mathrm{C}_{3} \mathrm{~N}_{4} / \mathrm{DEU}-$ 51(Fe) $\mathrm{C}_{3} \mathrm{~N}_{4} / \mathrm{DEU}-51(\mathrm{Fe})$ exhibited a high $\mathrm{Cr}(\mathrm{VI})$ reduction, however when the $\mathrm{C}_{3} \mathrm{~N}_{4} / \mathrm{DEU}-51(\mathrm{Fe})$ concentration increased from 1. $6 \mathrm{mg} / \mathrm{L}$ up to $4.0 \mathrm{mg} / \mathrm{L}$, no significant improvement of $\mathrm{Cr}(\mathrm{VI})$ decrease was observed. When the catalyst concentration is higher than that an optimal value $\left[\mathrm{C}_{3} \mathrm{~N}_{4} / \mathrm{DEU}-51(\mathrm{Fe})\right.$ catalyts concentration $\left.(>1.2 \mathrm{mg} / \mathrm{L})\right]$; excess photocatalyst vould cause accumulation of nano composite which is independent and elevated the opacity.

Table 1. Surface Properties of $\mathrm{C}_{3} \mathrm{~N}_{4} / \mathrm{DEU}-51(\mathrm{Fe})$.

\begin{tabular}{|c|c|c|c|}
\hline Samples & $\operatorname{BET}\left(m^{2} g^{-1}\right)^{a}$ & $\mathrm{~V}\left(\mathrm{ccg}^{-1}\right)^{\mathrm{b}}$ & $\mathrm{D}(\mathrm{nm})^{\mathrm{c}}$ \\
\hline $\mathrm{C}_{3} \mathrm{~N}_{4} / \mathrm{DEU}-51(\mathrm{Fe})(1.6 \mathrm{mg})$ & 22.04 & 0.093 & 1.92 \\
\hline $\mathrm{C}_{3} \mathrm{~N}_{4}(0.70 \mathrm{mg})$ & 13.50 & 0.021 & 1.42 \\
\hline $\mathrm{C}_{3} \mathrm{~N}_{4} / \mathrm{DEU}-51(\mathrm{Fe})(0.5 \mathrm{mg})$ & 17.90 & 0,067 & 1.72 \\
\hline $\left.\mathrm{C}_{3} \mathrm{~N}_{4} / \mathrm{DEU}-51(\mathrm{Fe}) 1 \mathrm{mg}\right)$ & 18.50 & 0,076 & 1.83 \\
\hline $\mathrm{C}_{3} \mathrm{~N}_{4} / \mathrm{DEU}-51(\mathrm{Fe})(2 \mathrm{mg})$ & 19.90 & 0.081 & 1.79 \\
\hline DEU-51(Fe) $(0.90 \mathrm{mg})$ & 12.80 & 0.070 & 1.45 \\
\hline
\end{tabular}

a: BET specific surface. b: Total pore volüme. $c$ : The pore diameter.

Table 2. Effects of doping content of $\mathrm{C}_{3} \mathrm{~N}_{4}$ in the $1.6 \mathrm{mg} / \mathrm{L} \mathrm{C}_{3} \mathrm{~N}_{4} / \mathrm{DEU}-51(\mathrm{Fe})$ on the removals of Cr(VI).

\begin{tabular}{|c|c|c|c|c|}
\hline $\begin{array}{l}\mathrm{C}_{3} \mathrm{~N}_{4} \\
\text { Concen } \\
\text { tration } \\
(\mathrm{mg} / \mathrm{L})\end{array}$ & $\begin{array}{l}\text { Cr(VI) } \\
\text { Concen } \\
\text { tration } \\
(\mathrm{mg} / \mathrm{L})\end{array}$ & $\begin{array}{l}\mathrm{Cr}(\mathrm{VI}) \\
\text { removal } \\
\text { efficiency } \\
(\%)\end{array}$ & $\begin{array}{c}\text { Cr(III) } \\
\text { Concen } \\
\text { tration } \\
\text { (mg/L)after } \\
\text { Photocatalysis } \\
\end{array}$ & $\begin{array}{c}\text { Remaining } \\
\text { Cr(VI) } \\
\text { Concen } \\
\text { tration } \\
(\mathrm{mg} / \mathrm{L}) \\
\end{array}$ \\
\hline 0.05 & 6 & 45 & 1.60 & 3.30 \\
\hline 0.10 & 6 & 55 & 1.80 & 2.70 \\
\hline 0.30 & 6 & 65 & 2.20 & 2.10 \\
\hline 0.70 & 6 & 93 & 5.59 & 0.42 \\
\hline 1.00 & 6 & 92 & 5.52 & 0.48 \\
\hline 1.50 & 6 & 92 & 5.52 & 0.48 \\
\hline 2.30 & 6 & 92 & 5.52 & 0.48 \\
\hline 5.00 & 6 & 92 & 5.52 & 0.48 \\
\hline
\end{tabular}


Table 3. Effects of $\mathrm{C}_{3} \mathrm{~N}_{4} / \mathrm{DEU}-51(\mathrm{Fe})$ concentrations on the removal of $\mathrm{Cr}(\mathrm{VI})$.

\begin{tabular}{ccccc}
\hline $\begin{array}{c}\mathrm{C}_{3} \mathrm{~N}_{4} / \mathrm{DEU}-51(\mathrm{Fe}) \\
\begin{array}{c}\text { Concen } \\
\text { tration }\end{array}\end{array}$ & $\begin{array}{c}\mathrm{Cr}(\mathrm{VI}) \text { concen } \\
\text { tration } \\
(\mathrm{mg} / \mathrm{L})\end{array}$ & $\begin{array}{c}\mathrm{Cr}(\mathrm{VI}) \text { removal efficiency } \\
(\%)\end{array}$ & $\begin{array}{c}\mathrm{Cr}(\mathrm{III}) \text { concentration } \\
\text { (mg/L) } \\
\text { after photocatalysis }\end{array}$ & $\begin{array}{c}\text { Remaining } \mathrm{Cr}(\mathrm{VI}) \operatorname{concen} \\
\text { tration }(\mathrm{mg} / \mathrm{L})\end{array}$ \\
\hline 0.1 & 6 & 34 & 1.10 & 3.96 \\
0.3 & 6 & 55 & 1.40 & 2.70 \\
1.8 & 6 & 65 & 2.20 & 1.80 \\
1.2 & 6 & 70 & 5.58 & 0.42 \\
1.6 & 6 & 93 & 5.52 & 0.54 \\
1.8 & 6 & 91 & 5.52 & 0.54 \\
2.5 & 6 & 91 & 5.52 & 0.54 \\
4.0 & 6 & 91 & 5.52 & 0.54 \\
\hline
\end{tabular}

However, this cause a reduction in sun ligth distibution in order to protect the effect of some solid particles [32]. At high nanocomposite levels in aquatic media asteric effect can be observed. Under these conditions the granule-granule interaction can musk the sun ligth diffusation and lowered the active reaction sites.

3.8 Effect of photooxidation times under sun light at $1.2 \mathrm{mg} / \mathrm{L} \mathrm{C}_{3} \mathrm{~N}_{4} / \mathrm{DEU}-\mathbf{5 1}(\mathrm{Fe})$ concentrations on the removal of $\mathrm{Cr}(\mathrm{VI})$ at $0.7 \mathrm{mg} / \mathrm{L} \mathrm{C}_{3} \mathrm{~N}_{4}$ concentration at initial $6 \mathrm{mg} / \mathrm{L} \mathrm{Cr}(\mathrm{VI})$ at a sun light power of $65 \mathrm{~mW} / \mathrm{m}^{2}$ after increasing photodegradation times (5 min, 15, 35, 60 and $90 \mathrm{~min}$ )

As the photooxidation times were increased from $5 \mathrm{~min}$ up to 15 min the $\mathrm{Cr}(\mathrm{VI})$ yields increased from $45 \%$ up to $93 \%$ under sun light (Table 4). The maximum $\mathrm{Cr}(\mathrm{VI})$ reduction to $\mathrm{Cr}(\mathrm{III})$ was found after 15 min contacting with $65 \mathrm{~mW} / \mathrm{m}^{2}$ sun light. Further increase of time did not affect the $\mathrm{Cr}(\mathrm{VI})$ removals. Data obtained from this study showed that the Cr(VI) reduction to $\mathrm{Cr}$ (III) depletes with attenuation of photodegradation period. It can speculated that longer retention time, in an elevated ratio of contact and at long contact times; hydroxyl radicals were not achieved for $\mathrm{Cr}(\mathrm{VI})$ reduction. As a result, low conversion rates was observed [33]. At a shorter residence time, $\mathrm{Cr}(\mathrm{III})$ have a lower colloid forming capacity with the $\mathrm{OH}$ anions produced from the photooxidation of $\mathrm{Cr}(\mathrm{VI})$ [33]. The enhancement effect is reduced with decreasing residence time. Jing et al. observed that the photoremoval efficiency of MIL-68(Fe) on the treatment of $\mathrm{Cr}(\mathrm{VI})$ in different media under UV light depends on illumination time [34]. The optimum illumination time for maximum removal of $\mathrm{Cr}(\mathrm{VI})(87 \%)$ was obtained as $60 \mathrm{~min}$. In our study, the optimum time and the maximum $\mathrm{Cr}(\mathrm{VI})$ yields were found to be higher than the study by Jing et al. [34].

3.9 Effects of increasing sun light powers on the removals of $\mathrm{Cr}(\mathrm{VI})$ photoremovals at $1.2 \mathrm{mg} / \mathrm{L}$ $\mathrm{C}_{3} \mathrm{~N}_{4} / \mathrm{DEU}-\mathbf{5 1}(\mathrm{Fe})$ concentration at $0.7 \mathrm{mg} / \mathrm{L} \mathrm{C}_{3} \mathrm{~N}_{4}$ concentration at initial $6 \mathrm{mg} / \mathrm{L} \mathrm{Cr(VI)}$ at a sun light power of $65 \mathrm{~mW} / \mathrm{m}^{2}$ after 15 min photooxidation

As the sun light powers were increased from $25 \mathrm{~mW} / \mathrm{m}^{2}$ at $12: 00$ in winter to $80 \mathrm{~mW} / \mathrm{m}^{2}$ at 12:00 in summer; the $\mathrm{Cr}(\mathrm{VI})$ removals increased from $34 \%$ up to $97 \%$ (Table 5). The $\mathrm{Cr}(\mathrm{VI})$ yields increased from $34 \%$ to $45 \%$, to $78 \%$ and to $97 \%$ as the sun light powers increased during season. The $\mathrm{Cr}(\mathrm{VI})$ removals were at medium levels (45\% and $78 \%$ ) at medium sun light powers ( 35 and $55 \mathrm{~mW} / \mathrm{m}^{2}$ ); since the sun was not so effective in the photooxidation. Sun light corresponds for the wavelength and gap energy of $\mathrm{C}_{3} \mathrm{~N}_{4} / \mathrm{DEU}-51(\mathrm{Fe})$ during contacting sun wavelength. The photon flux is important in the photocatalytic processes. The UV has a major influence in the removal of $\mathrm{Cr}(\mathrm{VI})$ since its influence in the production of $\mathrm{OH} \bullet$ radicals at elevated amount. A rise in light strength cause to improve the photocatalytic rates. In this study contrarily to the studies performed by Asadi et al. at high sun light powers (55 and $80 \mathrm{~mW} / \mathrm{m}^{2}$ in spring and in summer) electron hole pairs did not separate and they did not compete with electronhole recombination [35]. Zou et al. also mentioned that treatment of $\mathrm{Cr}(\mathrm{VI})$ and total chromium by Fe-nanoparticles depend on sun light powers [36]. They found that the majority of $\mathrm{Cr}(\mathrm{VI})$ presented in wastewater was likely reduced to $\mathrm{Cr}$ (III) at high sun light powers such as $80-90 \mathrm{~mW} / \mathrm{m}^{2}$.

\subsection{Effect of $\mathrm{pH}$ on the $\mathrm{Cr}(\mathrm{VI})$ reductions}

The studies were performed in the $\mathrm{pH}$ range $(2,5-8,5)$ for $6 \mathrm{mg} / \mathrm{L} \mathrm{Cr}(\mathrm{VI})$ dose and $1.2 \mathrm{mg} / \mathrm{L}$ of $\mathrm{C}_{3} \mathrm{~N}_{4} / \mathrm{DEU}-51$ (Fe) dosage and a $\mathrm{C}_{3} \mathrm{~N}_{4}$ level of $0.7 \mathrm{mg} / \mathrm{L}$ at a temperature of $42^{\circ} \mathrm{C}$. $\mathrm{Cr}(\mathrm{VI})$ yield is relevant with $\mathrm{pH}$ and the maximum $\operatorname{Cr}(\mathrm{VI})$ yield $(99.8 \%)$ is obtained at $\mathrm{pH} 2.5$ (Table 6). The $\mathrm{pH}$ in the beginning of the study has an important effect on the $\mathrm{Cr}(\mathrm{VI})$ in wastewater, and this affect the photoremoval of $\mathrm{Cr}(\mathrm{VI})$ [37][41].

At high $\mathrm{pH}$ levels the removals of $\mathrm{Cr}(\mathrm{VI})$ depleted since $\mathrm{pH}$ pzc of $\mathrm{C}_{3} \mathrm{~N}_{4}$ /DEU - 51(Fe) is around 4.2 [41]. At negative surface charges the production of $\mathrm{Cr}(\mathrm{VI})$ species decreased. $\mathrm{HCrO}_{4}{ }^{-}$ accumulates under $\mathrm{pH} 4$ and 5 and is sorbed on the nanocomposite superficial surface. At $\mathrm{pH}>3$, important quantity of $\mathrm{Cr}_{2} \mathrm{O}_{4}{ }^{2-}$ and $\mathrm{Cr}_{2} \mathrm{O}_{7}{ }^{2-}$ were found [42],[43]. $\mathrm{Cr}$ (VI) yields raised at low pH values [44]. At pH 2.5, 99.8\% of the $\mathrm{Cr}(\mathrm{VI})$ decreased after $15 \mathrm{~min}$. At pH of 5.0, and 8.5, the yield after 15 min irradiation were $60 \%$, and $30 \%$, respectively (Table 7). $\mathrm{Cr}(\mathrm{VI})$ reduction rates were maximum at acidic $\mathrm{pH}$ than at neutral or basic $\mathrm{pH}$ conditions. This can be explained by the big removal ratio of $\mathrm{Cr}(\mathrm{VI}) / \mathrm{Cr}(\mathrm{III})$ at lower $\mathrm{pH}$.

As the $\mathrm{pH}$ was decreased, the main thermodynamic power for $\mathrm{Cr}(\mathrm{VI})$ removal increases [45]. At high $\mathrm{pH}$, the molecular oxygen levels is higher than for the $\mathrm{Cr}(\mathrm{VI})$ and $\mathrm{O}_{2}$. This resultnng in with low $\mathrm{Cr}(\mathrm{VI})$ yields. The $\mathrm{Cr}(\mathrm{VI})$ yield elevated at low $\mathrm{pH}$, and improve the rate by corrosion of Fe. $\mathrm{pH}$ is one of the important since has an significant effect on photocatalysis [46]. At lower value of $\mathrm{pH}(5.0)$, the $\mathrm{Cr}(\mathrm{VI})$ yield was $60 \%$. When the $\mathrm{pH}$ was $8.5,30 \%$ removal was obtained. The results indicated that low $\mathrm{pH}$ was favorable for the removal of chromium. Under acidic $\mathrm{pH}$ condition, the electrostatic attraction between $\mathrm{C}_{3} \mathrm{~N}_{4}$ /DEU 51( $\mathrm{Fe})$ the and $\mathrm{Cr}$ ion increases. Jing et al., also observed that the low $\mathrm{Cr}(\mathrm{VI})$ yields via photodegradation was strongly effected by the $\mathrm{pH}$ value of the medium[34]. The $\mathrm{Cr}$ (VI) photooxidation percentage increased to $98 \%$ when the $\mathrm{pH}$ increased to 3.0 [34],[47]. 
Table 4. Effects of photooxidation times on $\mathrm{Cr}(\mathrm{VI})$ removals at a sun light power of $65 \mathrm{~mW} / \mathrm{m}^{2}$.

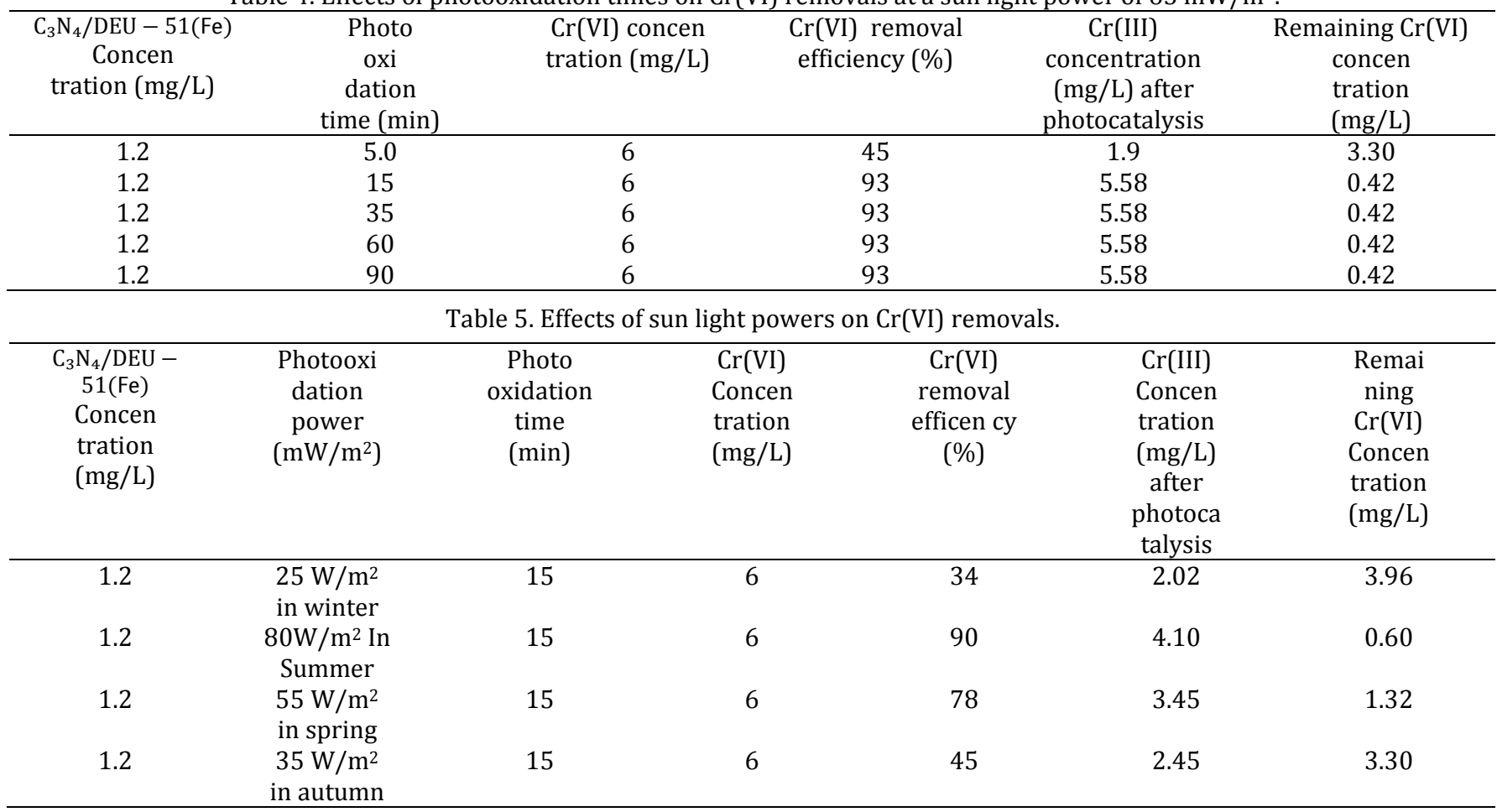

Table 6. Effects of $\mathrm{pH}$ on $\mathrm{Cr}(\mathrm{VI})$ removals.

\begin{tabular}{cccccc}
\hline $\begin{array}{c}\mathrm{C}_{3} \mathrm{~N}_{4} / \mathrm{DEU}-51(\mathrm{Fe}) \\
\begin{array}{c}\text { concen } \\
\text { tration (mg/L) }\end{array}\end{array}$ & $\begin{array}{c}\mathrm{Cr}(\mathrm{VI}) \text { concen } \\
\text { tration } \\
(\mathrm{mg} / \mathrm{L})\end{array}$ & $\begin{array}{c}\mathrm{Cr}(\mathrm{VI}) \text { removal } \\
\text { efficiency (\%) }\end{array}$ & $\begin{array}{c}\mathrm{Cr}(\mathrm{III}) \text { concentration } \\
\text { (mg/L) after } \\
\text { photocatalysis }\end{array}$ & $\begin{array}{c}\text { Remaining } \\
\mathrm{Cr}(\mathrm{VI}) \\
\text { concentra } \\
\text { tion }(\mathrm{mg} / \mathrm{L})\end{array}$ \\
\hline 1.2 & 2.5 & 6 & 99.8 & 5.70 & 0.012 \\
1.2 & 5.0 & 6 & 60.0 & 2.40 & 2.400 \\
1.2 & 8.5 & 6 & 30.0 & 1.02 & 4.200 \\
\hline
\end{tabular}

Table 7. Langmuir Hinshelwood kinetic for photocatalytic reduction of Cr(VI).

\begin{tabular}{cccc}
\hline $\begin{array}{c}\mathrm{C}_{3} \mathrm{~N}_{4} / \mathrm{DEU}-51(\mathrm{Fe}) \\
\text { Concentration }(\mathrm{mg} / \mathrm{L})\end{array}$ & $\begin{array}{c}\mathrm{kLH} \\
\text { (unitless) }\end{array}$ & $\mathrm{R}^{2}$ \\
\hline 0.1 & 0.204 & 0.018 & 0.99 \\
0.3 & 0.308 & 0.032 & 0.99 \\
0.8 & 0.442 & 0.042 & 0.99 \\
1.0 & 0.490 & 0.065 & 0.99 \\
1.2 & 0.940 & 0.078 & 0.99 \\
1.6 & 0.720 & 0.043 & 0.99 \\
\hline
\end{tabular}

3.11 Photocatalytic removal mechanism of $\operatorname{Cr}(\mathrm{IV})$ by $\mathrm{C}_{3} \mathrm{~N}_{4} / \mathrm{DEU}-\mathbf{5 1}(\mathrm{Fe})$

During photocatalysis $\mathrm{C}_{3} \mathrm{~N}_{4} / \mathrm{DEU}-51(\mathrm{Fe})$ is excited by sorption of electrons of sun light equivalent or bigger than the band gap Eg. This cause to exciting of a photon from the valence band to the conduction band. $\mathrm{Eg}$ of $\mathrm{C}_{3} \mathrm{~N}_{4} / \mathrm{DEU}-51(\mathrm{Fe})$ is around $2.4 \mathrm{eV}$, relevant to ca. $320 \mathrm{~nm}$. For this reason, $\mathrm{C}_{3} \mathrm{~N}_{4} / \mathrm{DEU}-51(\mathrm{Fe})$ has to be affected with sun light. The photon-hollow redox reactions is a quick phenomenon $(<80$ split-second in a $\mathrm{C}_{3} \mathrm{~N}_{4} / \mathrm{DEU}-51(\mathrm{Fe})$ [48],[49]). With chemical processes the photon conduction proceses occurred between $\mathrm{h}^{+} v_{\mathrm{B}}$ or $e^{-} \mathrm{CB}$ and different matters on the around of $\mathrm{C}_{3} \mathrm{~N}_{4} / \mathrm{DEU}-51(\mathrm{Fe})$ [50], [51]. The photon receivers decreased by photons in conduction band and releasing matters can be oxidized by $\mathrm{h}^{+} v_{\mathrm{B}}$ [52]. The redox reactions occurred between conduction band and valance band. Hydroxyl radicals $(\mathrm{HO} \bullet$ ) releasing by the redox reaction between valence band and conduction band adsorbed to the wastewater and to the surrounding of the hydroxyls are oxidizing compounds [51]. The reactive oxygen species such as $\left(\mathrm{HO}_{2} \bullet / \mathrm{O}_{2} \bullet^{-}\right)$, are also generated from $\mathrm{Cr}(\mathrm{III})$ by transformation of $\mathrm{Cr}(\mathrm{IV}) . \mathrm{Cr}(\mathrm{V})$ and $\mathrm{Cr}(\mathrm{IV})$ can be dissolved and it can be reacted with $\mathrm{Cr}(\mathrm{V})$ and $\mathrm{Cr}(\mathrm{IV})$. Cr(III) can be oxidized by valence band/hydroxyl radical couple [37],[53],[55]. Cr(III) was obtained as the end product on the $\mathrm{C}_{3} \mathrm{~N}_{4} / \mathrm{DEU}-51(\mathrm{Fe})$ surface [53],[54],[56]. This is possible because the accumulation of $\operatorname{Cr}(\mathrm{III})$ cause to decrease the activation of $\mathrm{C}_{3} \mathrm{~N}_{4} / \mathrm{DEU}-51(\mathrm{Fe})$ and this prevents the transportation of the electrons by redox reactions [57],[58].

This provides very advantageous in the photocatalytic systems for $\mathrm{Cr}(\mathrm{VI})$ depletion from effluents. The mechanism responsible for the convertion of $\mathrm{Cr}(\mathrm{VI})$ to $\mathrm{Cr}(\mathrm{III})$ can be explained as follows: $\mathrm{Cr}(\mathrm{VI})$ in excited state could be reduced by the electron 
donor in the conduction band of $\mathrm{C}_{3} \mathrm{~N}_{4} / \mathrm{DEU}-51(\mathrm{Fe})$ with the aid of $\mathrm{H}^{+}$. The photoreduction of $\mathrm{CrO}_{4}$ mediated by the electron donor in oxygenated textile industry wastewaters. The possible mechanism of the photochemical reduction of $\mathrm{Cr}(\mathrm{VI})$ was proposed following Eqs. 1-4 [57],[58].

$$
\begin{aligned}
& \mathrm{Cr}(\mathrm{VI})+\mathrm{ROH}+\mathrm{OH}^{-}+h v \rightarrow \mathrm{Cr}(\mathrm{VI})+\mathrm{OH}^{-}+\mathrm{H}_{2} \mathrm{O} \\
& \mathrm{C}_{3} \mathrm{H}_{4} / \mathrm{DEU}-51(\mathrm{Fe})+\mathrm{h} v \rightarrow \mathrm{h}+\left[\mathrm{C}_{3} \mathrm{H}_{4} / \mathrm{DEU}-51\left(\mathrm{Fe}^{+}\right)\right]+\mathrm{OH}^{-} \\
&+\mathrm{e}^{-}\left[\mathrm{C}_{3} \mathrm{H}_{4} / \mathrm{DEU}-51(\mathrm{Fe})\right. \\
& \mathrm{e}^{-}\left[\mathrm{C}_{3} \mathrm{H}_{4} / \mathrm{DEU}-51(\mathrm{Fe})\right]+\mathrm{OH}^{-} \\
& \rightarrow \mathrm{e}^{-}\left[\mathrm{C}_{3} \mathrm{H}_{4} / \mathrm{DEU}-51(\mathrm{Fe})\right] \\
& \mathrm{Cr}(\mathrm{VI})+\mathrm{OH}^{-}+\mathrm{e}^{-} \rightarrow \mathrm{Cr}(\mathrm{III})+\mathrm{H}_{2} \mathrm{O}
\end{aligned}
$$

\subsection{Reusability of $\mathrm{C}_{3} \mathrm{~N}_{4} / \mathrm{DEU}-\mathbf{5 1}(\mathrm{Fe})$}

The photocatalytic activity of $\mathrm{C}_{3} \mathrm{~N}_{4} / \mathrm{DEU}-51(\mathrm{Fe})$ does not significantly reducted after sequential five cycles for the removal of $\mathrm{Cr}(\mathrm{VI})$ to $\mathrm{Cr}(\mathrm{III})$. This showed that $\mathrm{C}_{3} \mathrm{~N}_{4} / \mathrm{DEU}-51(\mathrm{Fe})$ exhibited high resistance and can be utilized for sequential removal of $\mathrm{Cr}(\mathrm{VI})$ photoreduction (Table 8).

\begin{tabular}{cccccc}
\multicolumn{6}{c}{ Table 8. Recovery of $\mathrm{C}_{3} \mathrm{~N}_{4} / \mathrm{DEU}-51(\mathrm{Fe})$} \\
\hline $\mathrm{C}_{3} \mathrm{~N}_{4} /$ & $\mathrm{Cr}(\mathrm{VI})$ & $\mathrm{Cr}(\mathrm{VI})$ & $\mathrm{Cr}(\mathrm{VI})$ & $\mathrm{Cr}(\mathrm{VI})$ & $\mathrm{Cr}(\mathrm{VI})$ \\
$\mathrm{DEU}-$ & remov & remov & remov & remov & remov \\
$51(\mathrm{Fe})$ & al & al & al & al & al \\
$(\mathrm{mg} / \mathrm{L})$ & $(\%)$ & $(\%)$ & $(\%)$ & $(\%)$ & $(\%)$ \\
& first & second & third & fourth & five \\
\hline $1,2 \mathrm{RUN}-1$ & 98 & 98 & 98 & 97 & 97 \\
$1,2 \mathrm{RUN}-2$ & 98 & 98 & 98 & 97 & 97 \\
$1,2 \mathrm{RUN}-3$ & 98 & 98 & 97 & 97 & 96 \\
\hline
\end{tabular}

\section{Conclusions}

$\mathrm{C}_{3} \mathrm{~N}_{4}$ /DEU - 51(Fe) was produced in a research laboratory and can be used was as a heterocatalyst to remove $\mathrm{Cr}(\mathrm{VI})$ from wastewater under sun-light applications. The novel composite is effective of $\mathrm{Cr}(\mathrm{VI})$ removal. $\mathrm{pH}$ has a successfully effect on the removal of $\mathrm{Cr}(\mathrm{VI})$ photodegradation under a sun light power of $80 \mathrm{~mW} / \mathrm{m}^{2}$. XRD analysis showed that $\mathrm{C}_{3} \mathrm{~N}_{4}$ /DEU $-51(\mathrm{Fe})$ exhibited good crystallinity. The FTIR spectrums showed that the corresponded bands in the photocatalytic reaction are related to carboxyl groups of the composite center and it is associated with the $\mathrm{C}-\mathrm{H}$-vibration. The TEM micrographs showed that $\mathrm{C}_{3} \mathrm{~N}_{4}$ was present in the $\mathrm{C}_{3} \mathrm{~N}_{4} / \mathrm{DEU}-51(\mathrm{Fe})$. The optimum $\mathrm{pH}$ in $\mathrm{Cr}(\mathrm{VI})$ removal by $\mathrm{C}_{3} \mathrm{~N}_{4} / \mathrm{DEU}-51(\mathrm{Fe})$ was found at $\mathrm{pH} 2,5 . \mathrm{Cr}(\mathrm{VI})$ was reduced with a maximum yield of $92 \%$ to $\mathrm{Cr}(\mathrm{III})$ at $0.7 \mathrm{mg} / \mathrm{L} \mathrm{C}_{3} \mathrm{~N}_{4}$ concentration using $1.2 \mathrm{mg} / \mathrm{L} \mathrm{C}_{3} \mathrm{~N}_{4} / \mathrm{DEU}-51(\mathrm{Fe})$ composite concentration after 15 min photooxidation time in summer at $42{ }^{\circ} \mathrm{C}$. The photocatalytic performance of $\mathrm{C}_{3} \mathrm{~N}_{4} / \mathrm{DEU}-51(\mathrm{Fe})$ was enhanced by doping of $\mathrm{C}_{3} \mathrm{~N}_{4}$. The photo-catalytic reduction rate of $\mathrm{Cr}(\mathrm{VI})$ was expressed by LangmuirHinshelwood Kinetic Model. The $k_{\mathrm{r}}$ and the $K_{\mathrm{LH}}$ were obtained as 0.940 unitless and $0.078 \mathrm{mg} / \mathrm{L}-\mathrm{min}$, respectively. $\mathrm{C}_{3} \mathrm{~N}_{4} / \mathrm{DEU}-51(\mathrm{Fe})$ was reused with a $\mathrm{Cr}(\mathrm{VI})$ yield of $97 \%$ after five sequential treatment trips.

\section{References}

[1] Zhao G, Li J, Ren X, Chen C, Wang X. "Few-layered graphene oxide nano sheets as superior sorbents for heavy metal ion pollution management". Environmantal Science and Technology, 45, 10454-10462, 2011.
[2] Ross D, Ketterings Q. Recommended Methods for Determining Soil Cation Exchange Capacity. Publisher University of Delaware Newark DE, Northeastern United States, 1995.

[3] Mohammed AS, Kapri A, Goel R. "Heavy metal pollution: source, impact and remedies". Biomanagement of Metal-Contaminated Soils, 9(1), 1-28, 2011.

[4] Aremu MO, Atolaiye BO, Labaran L. "Environmental implication of metal concentrations in soil, plant foods and pond in area around the derelict udege mines of nasarawa state". Nigeria Chemical Society Ethiopia, 24(3), 351-360, 2010.

[5] Kieber RJ, Willey JD, Zvalaren SD. “Chromium speciation in rainwater: temporal variability and atmospheric deposition". Environmantal Science and Technology, 36, 5321-5327, 2002.

[6] Testa JJ, Grela MA, Litter MI.“Heterogeneous photocatalytic reduction of chromium (VI) over $\mathrm{TiO}_{2}$ particles in the presence of oxalate: involvement of $\mathrm{Cr}(\mathrm{VI})$ species". Environmental Science and Technology, 38, 1589-1594, 2014.

[7] Qiu B, Xu CX, Sun DZ, Wei HG, Zhang X, Guo J, Wang Q, Rutman D, Guo ZH, Wei SY. "Polyaniline coating on carbon fiber fabrics for improved hexavalent chromium removal". RSC Advances, 4, 29855-29865, 2014.

[8] Lv ZF, Liang CS, Cui JY, Zhang YA, Xu S. "A facile route for the synthesis of mesoporous melamine-formaldehyde resins for hexavalent chromium removal". RSC Advances, 5, 18213-18217, 2015.

[9] Cai L, Xiong X, Liang N, Long Q. " Highly effective and stable $\mathrm{Ag}_{3} \mathrm{PO}_{4}-\mathrm{WO}_{3} / \mathrm{MWCNTs}$ photocatalysts for simultaneous $\mathrm{Cr}(\mathrm{VI})$ reduction and orange II degradation under visible light irradiation". Applied Surface Science, 353, 939-948, 2015.

[10] Rajeshwar K, Chenthamarakshan CR, Goeringer S, Djukic M. "Titania-based heterogeneous photocatalysis. Materials, mechanistic issues, and implications for environmental remediation". Pure and Applied Chemistry, 73(12), 1849-1860, 2001.

[11] Bailey SE, Olin TJ, Bricka RM, Adrian DD. "A review of pontentially low-cost sorbents for heavy metals". Water Research, 33(11), 2469-2479, 1999.

[12] Dresselhaus MS, Thomas IL. "Alternative energy technologies". Nature, 414, 332-337, 2014.

[13] Maeda K, Takata T, Ha M, Saito N, Domen KJ. “GaN: ZnO solid solution as a photocatalyst for visible-light-driven overall water splitting". American Chemical Society, 127, 8286-8287, 2005.

[14] Niu S-f, Liu Y, Xu X-h, Lou Z-h. "Removal of hexavalent chromium from aqueous solution by iron nanopartlcles". Journal of Zhejiang University, 6B(10), 1022-1027, 2005.

[15] Huang W, Liua N, Zhanga X, Wub M, Tang L. "Metal organic framework g- $\mathrm{C}_{3} \mathrm{~N}_{4} /$ MIL-53(Fe) heterojunctions with enhanced photocatalytic activity for $\mathrm{Cr}(\mathrm{VI})$ reduction under visible light". Applied Surface Science, 425, 107-116, 2017.

[16] Niu P, Zhang L, Liu G, Cheng H-M. "Graphene-like carbon nitride nanosheets for improved photocatalytic activities". Advanced Functional Materials, 22, 4763-4770, 2012.

[17] Gürkan R, Ulusoy HI, Akçay M. "Simultaneous determination of dissolved inorganic chromium species in wastewater/natural waters by surfactant sensitized catalytic kinetic spectrophotometry". Arabian Journal of Chemistry, 10, 450-460, 2017. 
[18] Akple MS, Low J, Wageh S, Al-Ghamdi AA, Yu J, Zhang J. "Enhanced visible light photocatalytic $\mathrm{H}_{2}$-production of g$\mathrm{C}_{3} \mathrm{~N}_{4} / \mathrm{WS} 2$ composite heterostructures". Applied Surface Science, 358, 196-203,2015.

[19] Wen J, Xie J, Yang Z, Shen R, Li H, Luo X, Li X. "Fabricating the robust $\mathrm{g}-\mathrm{C}_{3} \mathrm{~N}_{4}$ nanosheets/carbons/NiS multiple heterojunctions for enhanced photocatalytic $\mathrm{H}_{2}$ generation: an insight into the trifunctional roles of nanocarbons". ACS Sustain, Chemical Engineering, 5(3), 2224-2236, 2017.

[20] Cao K, Jiang Z, Zhang X, Zhang Y, Zhao J, Xing R, Yang S, Gao C, Pan F. "Highlywater-Selective hybrid membrane by incorporating $\mathrm{g}-\mathrm{C}_{3} \mathrm{~N}_{4}$ nanosheets into polymer matrix". Journal of Membrane Science, 490, 72-83, 2015.

[21] Llewellyn PL, Horcajada P, Maurin G, Devic T, Rosenbach N, Bourrelly S, Serre C, Vincent D, Loera-Serna S. "Linear alkanes in the flexible metal-organic-framework MIL53(Fe)". Journal of the American Chemical Society, 131, 13002-13008, 2009.

[22] Hu SZ, Ma L, You JG, Li FY, Fan ZP, Wang F, Liu FD, Gui JZ. "A simple andefficient method to prepare a phosphorus modified g- $\mathrm{C}_{3} \mathrm{~N}_{4}$ visible light photocatalyst". RSC Advances, 4, 21657-21663, 2014.

[23] Wang H, Yuan XZ, Wu Y, Zeng GM, Chen XH, Leng LJ, Li H. "Synthesis and applications of novel graphitic carbon nitride/metal-organic frameworks mesoporous photocatalyst for dyes removal". Applied Catalysis $B$, 174, 445-454, 2015.

[24] Hong J, Chen C, Bedoya FE, Kelsall GH, O’Hare D, Petit C. "Carbon nitridenanosheet/metal-organic framework nanocomposites with synergistic photocatalytic activities". Catalysis Science \& Technology, 6, 5042-5051, 2016.

[25] Du JJ, Yuan YP, Sun JX, Peng FM, Jiang X, Qiu LG, Xie AJ, Shen $\mathrm{YH}, \mathrm{Zhu}$ JF. "New photocatalysts based on MIL-53 metal-organic frameworks for the decolorization of methylene blue dye". Journal of Hazardous Materials, 190 , 945-951, 2011.

[26] He F, Chen G, Zhou Y, Yu Y, Zheng YS. "The facile synthesis of mesoporous $\mathrm{g}-\mathrm{C}_{3} \mathrm{~N}_{4}$ with highly enhanced photocatalytic $\mathrm{H}_{2}$ evolution performance". Chemical Communications, 51(90), 16244-16246, 2015.

[27] Zhu Z, Murugananthan M, Gu J, Zhang Y. "Fabrication of a Z-scheme g- $\mathrm{C}_{3} \mathrm{~N}_{4} / \mathrm{Fe}-\mathrm{TiO}_{2}$ photocatalytic composite with enhanced photocatalytic activity under visible light". Irradiation Catalysts, 8(3), 112-120, 2018.

[28] Zheng Y, Jiao Y, Chen J, Liu J, Liang J, Du A, Zhang W, Zhu Z, Smith SC, Jaroniec M, Lu GQ, Qiao SZ. "Nanoporous Graphitic- $\mathrm{C}_{3} \mathrm{~N}_{4} @$ @arbon Metal-free electrocatalysts for highly efficient oxygen reduction". Journal of the American Chemical Society, 133(50), 20116-20119, 2011.

[29] Wan SL, He F, Wu JY, Wan WB, Gu YW, Gao B, Hazard J. "Rapid and highly selective removal of lead from water using graphene oxide-hydrated manganese oxide nano composites". Journal of Hazardous Materials, 314, 32-40, 2016.

[30] Wang X, Liang Y, An W, Hu J, Zhu Y, Cui W. “Removal of chromium (VI) by a self-regenerating and metal free g$\mathrm{C}_{3} \mathrm{~N}_{4}$ /graphene hydrogel system via the synergy of adsorption and photo-catalysis under visible light". Applied Catalysis B: Environmental, 219, 53-62,_2017.
[31] Nguyen AT, Juang RS. "Photocatalytic degradation of pchlorophenol by hybrid $\mathrm{H}_{2} \mathrm{O}_{2}$ and $\mathrm{TiO}_{2}$ in aqueous suspensions under UV irradiation". Journal of Environmental Management, 147, 271-277, 2015.

[32] Zeghioud H, Khellaf N, Djelal H, Amrane A, Bouhelassa M. "Photocatalytic reactors dedicated to the degradation of hazardous organic pollutants: kinetics, mechanistic aspects and design". Chemical Engineering Communications, 203, 1415-1431, 2016.

[33] Zuo Y, Zhan, J, Wu T. "Effects of Monochromatic UV-Visible Light and Sunlight on Fe(III)-Catalyzed Oxidation of Dissolved Sulfur Dioxide". Journal of Atmospheric Chemistry, 50, 195-210, 2005.

[34] Jing F, Liang R, Xiong J, Chen R, Zhang S, Li Y. “MIL-68 (Fe) as an efficient visible-light-driven photocatalyst for the treatment of a simulated waste-water contain $\mathrm{Cr}$ (VI) and Malachite Green". Applied Catalysis B: Environmental, 206, 9-15, 2017.

[35] Assadi AA, Palau J, Bouzaza A, Wolbert D. "Modeling of a continuous photocatalytic reactor for isovaleraldehyde oxidation: Effect of different operating parameters and chemical degradation pathway". Chemical Engineering Research and Design, 91(7), 1307-1316, 2013.

[36] Zou Y, Wang X, Khan A, Wang P, Liu Y, Alsaedi A, Hayat T, Wang X. "Environmental remediation and application of nanoscale zero-valent iron and its composites for the removal of heavy metal ions". Environmental Science and Technology, 50(14), 7290-7304, 2016.

[37] Testa JJ, Grela MA, Litter MI. "Experimental evidence in favor of an initial one-electron-transfer process in the heterogeneous photocatalytic reduction of chromium (VI) over $\mathrm{TiO}_{2}$ ". Langmuir, 17, 3515-3517, 2001.

[38] Das DP, Parida K, De BR. "Photocatalytic reduction of hexavalent chromium in aqueous solution over titania pillared zirconium phosphate and titanium phosphate under solar radiation". Journal of Molecular Catalysis A: Chemical, 245, 217-224, 2006.

[39] Wang L, Wang N, Zhu L, Yu H, Tang H. "Photocatalytic reduction of $\mathrm{Cr}(\mathrm{VI})$ over different $\mathrm{TiO}_{2}$ photocatalysts and the effects of dissolved organic species". Journal of Hazardous Materials, 152(1), 93-99, 2008.

[40] Guo D, Wen R, Liu M, Guo H, Chen J, Weng W. "Facile fabrication of $\mathrm{g}-\mathrm{C}_{3} \mathrm{~N}_{4} / \mathrm{MIL}-53(\mathrm{Al})$ composite with enhanced photocatalytic activities under visible-light irradiation". Applied Organometallic Chemistry, 29, 690-697, 2015.

[41] Oladipo AA. "MIL-53 (Fe)-based photo-sensitive composite for degradation of organochlorinated herbicide and enhanced reduction of $\mathrm{Cr}(\mathrm{VI}) "$. Process Safety and Environmental Protection, 116, 413-423, 2018.

[42] Jiang F, Zheng Z, Xu Z, Zheng S, Guo Z, Chen L. "Aqueous $\mathrm{Cr}(\mathrm{VI})$ photoreduction catalyzed by $\mathrm{TiO}_{2}$ and sulfated $\mathrm{TiO}_{2}$ ". Journal of Hazardous Materials, 134(1-3), 94-103, 2006.

[43] Chakrabarti S, Chaudhuri B, Bhattacharjee S, Ray AK, Dutta BK. "Photoreduction of hexavalent chromium in aqueous solution in the presence of zincoxide as semiconductor catalyst". Chemical Engineering Journal, 153(1-3), 86-93, 2009.

[44] Kabra K, Chaudhary R. "Treatment of hazardous organic and inorganic compounds through aqueous-phase photocatalysis". Industrial \& Engineering Chemistry Research, 43(24), 7683-7696, 2004. 
[45] Cappelletti G, Bianchi CL, Ardizzone S. "Nano-titania assisted photoreduction of $\mathrm{Cr}(\mathrm{VI})$ : The role of the different $\mathrm{TiO}_{2}$ polymorphs". Applied Catalysis B: Environmental, 78(3-4), 193-201, 2008.

[46] Zhou M, Yu J, Cheng B. "Effects of Fe-doping on the photocatalytic activity of mesoporous $\mathrm{TiO}_{2}$ powders prepared by an ultrasonic method". Journal of Hazardous Materials, 137(3), 1838-1847, 2006.

[47] Ku Y, Jung IL. "Photocatalytic reduction of $\mathrm{Cr}(\mathrm{VI})$ in aqueous solutions by UV irradiation with the presence of titanium dioxide". Water Research, 35, 135-142, 2001.

[48] Hoffmann MR, Martin ST, Choi W, Bahnemann D. "Environmental applications of semiconductor photocatalysis”. Chemical Reviews, 95, 69-96, 1995.

[49] Grela MA, Loeb B, Restrepo GM, Lagorio MG. Román ES. Los Mecanismos De Destrucción. Ed. Miguel Blesa, Capítulo 5 en: Eliminación de Contaminantes por Fotocatálisis Heterogénea, $8^{\text {th }}$ ed. 125-162, La Plata, Buenos Aires, Argentina, 2004.

[50] Grela MA, Colussi AJ. "Kinetics of stochastic charge transfer and recombination events in semiconductor colloids, relevance to photocatalysis efficiency". The Journal of Physical Chemistry, 100, 18214-18221, 1996.

[51] Kamat PV. "Manipulation of charge transfer across semiconductor interface. A criterion that cannot be ignored in photocatalyst design". The Journal of Physical Chemistry Letters, 3, 663-671, 2012.

[52] Martin ST, Herrmann H, Hoffmann MR. "Time-resolved microwave conductivity. Part 2.-Quantum-sized $\mathrm{TiO}_{2}$, and the effect of adsorbates and light intensity on charge-carrier dynamics". Journal of the Chemical Society, Faraday Transactions, 90, 3323-3330, 1994.
[53] Meichtry JM, Brusa M, Mailhot G, Grela MA, Litter MI. "Heterogeneous photocatalysis of $\mathrm{Cr}(\mathrm{VI})$ in the presence of citric acid over $\mathrm{TiO}_{2}$ particles: relevance of $\mathrm{Cr}(\mathrm{V})$ citrate complexes". Applied Catalysis B, 71, 101-107, 2007.

[54] Meichtry JM, Colbeau-Justin C, Custo G, Litter MI. " $\mathrm{TiO}_{2}$ photocatalytic transformation of $\mathrm{Cr}(\mathrm{VI})$ in the presence of EDTA: comparison of different commercial photocatalysts and studies by time resolved microwave conductivity". Applied Catalysis B, 144, 189-195, 2014.

[55] Montesinos VN, Salou C, Meichtry JM, Colbeau-Justin C. "Litter MI Role of $\operatorname{Cr}($ III) deposition during the photocatalytic transformation of hexavalent chromium and citric acid over commercial $\mathrm{TiO}_{2}$ samples". Photochemical \& Photobiological Sciences, 15, 228-234, 2016.

[56] Ananpattarachai J, Kumket P, Tung TV, Kajitvichyanukul P. "Chromium (VI) removal using nano- $\mathrm{TiO}_{2} /$ chitosan film in photocatalytic System". International Journal of Environment and Waste Management, 16, 55-70, 2015.

[57] Wang N, Xu Y, Zhu L, Shen X, Tang H. "Reconsideration to the deactivation of $\mathrm{TiO}_{2}$ catalyst during simultaneous photocatalytic reduction of $\mathrm{Cr}(\mathrm{VI})$ and oxidation of salicylic acid". Journal of Photochemistry, 201(2-3), 121-127, 2009.

[58] Meichtry JM, Dillert R, Bahnemann D, Litter MI. "Application of the stopped flow technique to the $\mathrm{TiO}_{2}$ heterogeneous photocatalysis of hexavalent chromium in aqueous suspensions: comparison with $\mathrm{O}_{2}$ and $\mathrm{H}_{2} \mathrm{O}_{2}$ as electron acceptors". Langmuir, 31, 6229-6236, 2015. 